\title{
Explorant teràpies biotecnològiques contra les malalties neurodegeneratives
}

\author{
Carmen Agustín Pavón (deagusti@uji.es) \\ Universitat Jaume I
}

\section{Introducció}

Les malalties neurodegeneratives tenen una característica comuna: la pèrdua de funcionalitat neuronal, que culmina en la mort de les neurones. Aquestes malalties poden afectar diverses poblacions neuronals en el sistema nerviós central, com ara l'Alzheimer, o poblacions específiques, com pot ser l'esclerosi lateral amiotròfica (ELA) que afecta les motoneurones.

La prevalença de les malalties neurodegeneratives com són el Parkinson, l'Alzheimer, i fins i tot la rara malaltia de Huntington, s'està incrementant (Association, 2014). Això és en part per causa de l'augment dels estàndards de vida que propicien l'increment de l'esperança de vida y que desemboquen en un inexorable envelliment poblacional. Si tenim en compte altres malalties neurològiques, com poden ser les malalties neuropsiquiàtriques, que al seu torn són un factor de risc per al desenvolupament de la neurodegeneració, s'estima que fins a un terç de la població europea pateix malalties cerebrals cada any. Per tant, les malalties neurològiques constitueixen una enorme càrrega socioeconòmica.

En aquest escenari, és urgent desenvolupar noves aproximacions terapèutiques per a frenar l'increment en la incidència de les malalties neurodegeneratives. Aquestes teràpies s'han de fonamentar necessàriament en la ciència bàsica, ja que necessitem entendre el cervell per a poder tractar-lo. Com sovint recorda Ferran Martínez-García, catedràtic de fisiologia de la Universitat Jaume I, el cervell és la màquina més complexa de l'univers. Encara ens resta un llarg camí fins a entendre en profunditat les funcions cerebrals, els circuits neurals, els papers dels diferents tipus celllulars que formen part del nostre cervell (neurones, cèlllules glials), etc.

La nostra manca de coneixement profund de la funció cerebral no és l'únic problema amb el qual ens enfrontem. A l'hora de tractar les malalties neurodegeneratives ens trobem també amb dificultats de diagnòstic. La gran plasticitat del cervell provoca canvis compensatoris que poden mantenir la funcionalitat quan la neurodegeneració ja ha provocat mort cel-lular massiva. Per aquesta raó, quan el pacient arriba a la consulta mèdica amb símptomes, és possible que la neurodegeneració estiga ja molt avançada. Per això, un diagnòstic primerenc, quan la mort neuronal encara és incipient, faria possible el tractament efectiu de les malalties neurodegeneratives. Noves eines de diagnòstic basades en símptomes primerencs, que difereixen dels clàssics, ja estan posant-se en marxa. Per exemple, en malalties com el Parkinson, trastorns de tipus psiquiàtric o pèrdues de l'olfacte (anòsmia) precedeixen en diverses dècades els símptomes clínics (trastorns motors) (Doty i Kamath, 2014; Morley i altres, 2011). És imprescindible millorar les eines diagnòstiques 
per tal de poder iniciar els tractaments abans que la neurodegeneració avance. A banda dels diagnòstics per símptomes físics, és necessari identificar els marcadors genètics que poden predisposar a patir una malaltia neurodegenerativa. L'ús d'aquests biomarcadors, no obstant això, no està exempt de consideracions ètiques.

Un altre problema és la inexpugnabilitat del cervell. A diferència d'altres òrgans, el cervell està protegit per una barrera, anomenada barrera hematoencefàlica, que protegeix les neurones de l'exterior però també dificulta l'arribada dels fàrmacs. A més, mentre les cèllules d'òrgans com ara el fetge tenen una bona capacitat de regeneració, això no és cert per a les neurones. Fins i tot si aquestes es pogueren regenerar, encara ens quedaria el problema de les connexions entre els diversos nuclis que formen el cervell, ja que aquest no és un òrgan homogeni, sinó que les seues funcions es troben distribuïdes entre diversos nuclis.

Els tractaments farmacològics disponibles per a aquestes malalties són purament simptomàtics. Els fàrmacs no es dirigeixen contra la causa de la malaltia, que moltes vegades desconeixem, sinó simplement alleugen els seus símptomes. Per tant, els tractaments farmacològics actuals són incapaços d'aturar la progressió d'una malaltia neurodegenerativa. Per a millorar les perspectives d'aquestes malalties, necessitem idear nous tractaments que es dirigisquen a la causa de la malaltia i promoguen la regeneració. La biotecnologia ofereix interessants alternatives als tractaments actuals.

\section{La investigació biomèdica bàsica i les seues eines biotecnològiques}

\subsection{Importància dels models cel·lulars i animals per al disseny i comprovacions de les teràpies biotecnològiques}

La definició clàssica de malaltia és obsoleta. Fins i tot les malalties de les quals es coneix la causa presenten un ventall de símptomes que resulten de la complexa interacció entre la predisposició genètica, les influències ambientals (estil de vida, dieta, etc.) i d'altres factors encara desconeguts. Encara més, sota un mateix nom podem tenir una enorme varietat de malalties molt diferents (com a exemple més directe, el càncer, que no existeix com a tal, sinó que hi ha centenars de tipus de càncers diferents), o també una malaltia en concret pot afectar de manera molt diferent diversos pacients, segons factors com ara la història clínica, el sexe, etc. Davant d'aquestes deficiències, la medicina personalitzada pot ser la solució.

Una de les noves aproximacions per a estudiar la malaltia és la modelització d'aquesta en una placa de cultiu (com se sol dir, in vitro). Els biòlegs cel-lulars i moleculars extrauen cèl-lules als pacients i les cultiven per a comprovar-hi els efectes dels tractaments sobre la seua supervivència i funció. A més, emprant tisores moleculars ja s'han creat models de malalties neurològiques en cèlllules immortals i animals model. Per exemple, s'han creat neurones en placa similars a les dels pacients amb Parkinson i Alzheimer, i s'han pogut corregir les mutacions d'aquestes cèlllules i convertir-les en cèlllules sanes (Fong i altres, 2013). Aquestes cèllules no només ens permeten investigar els mecanismes de la malaltia i els seus possibles tractaments in vitro, també ens obrin la porta per a l'assaig de trasplantaments de cèllules al cervell.

Però no hem d'oblidar la frase aristotèlica: el tot no és el mateix que la suma de les parts. El cervell, no pot ser aïllat del cos, fins i tot si intentem modelar el seu ambient 


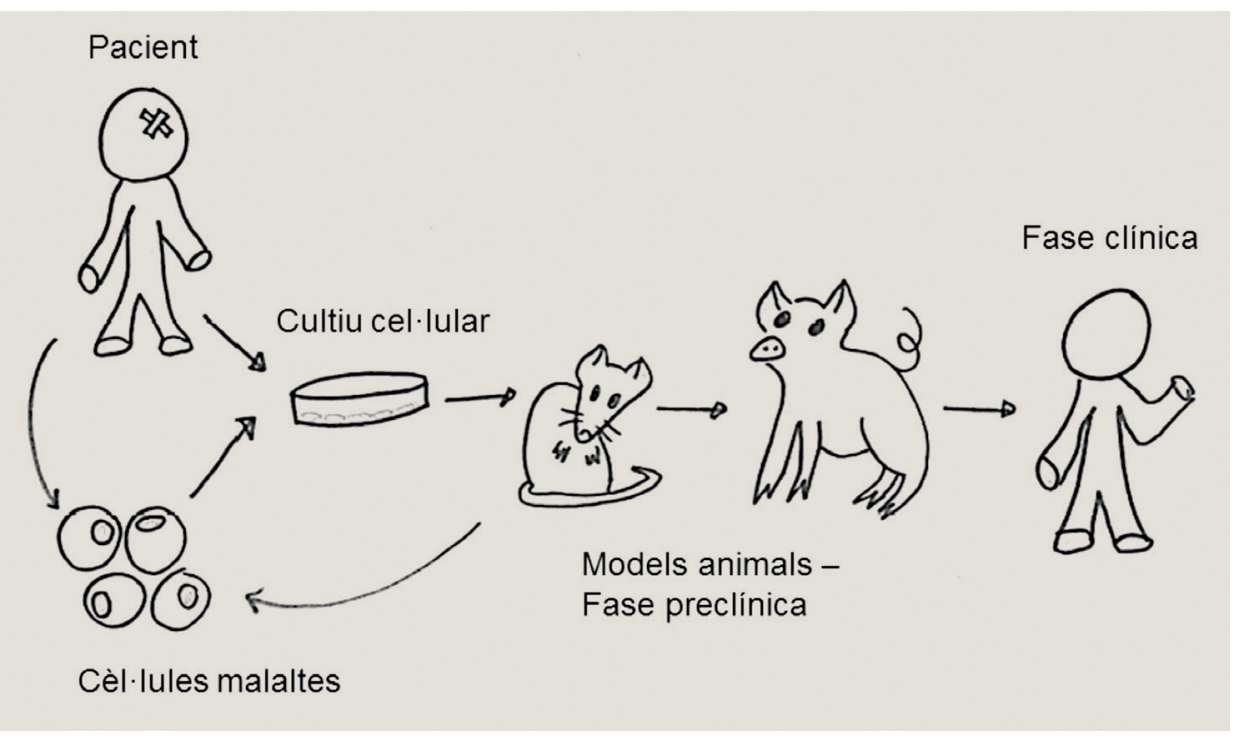

Figura 1. Seqüència d'estudi comprovació de nous tractaments.

en cultius conjunts de tots els seus tipus cel-lulars. Ara com ara, l'ús de models animals és necessari. En general, es prefereixen els ratolins per la seua extensa caracterització i facilitat de manipulació. Rosegadors i humans som quasi idèntics en l'aspecte molecular, però no compartim molts trets fisiològics. En tot cas, les noves teràpies biotecnològiques tenen una seqüència de generació: del cultiu al model de ratolí, al model de gran mamífer i a l'ésser humà (Figura 1).

Es poden obtenir cèlllules dels pacients o d'una línia cel-lular modificada perquè expresse la malaltia. El tractament experimental s'assajarà primerament sobre les cèllules en cultiu. A continuació, s'assajarà sobre ratolins o altres animals petits de laboratori. Normalment, si aquesta fase en animal de laboratori té èxit, la teràpia s'assajarà en un model animal més complex, com són els animals de granja, abans de passar a la clínica. Una vegada en clínica, el primer pas és comprovar la innocuïtat del tractament proposat, i només una vegada s'assegura que no té cap tipus d'efecte nociu per als pacients, es dissenyarà un assaig per a comprovar-ne l'eficàcia. El procés sencer pot tardar molts anys a finalitzar i només un percentatge molt petit d'assajos que tenen èxit en cultius cel-lulars o en animals arriba a l'última fase de l'assaig clínic.

\subsection{Les malalties rares com a model d'estudi d'altres malalties neurodegeneratives comunes}

Com hem explicat, el coneixement bàsic dels mecanismes de funcionament neuronal és imprescindible per al disseny de noves teràpies. És necessari comparar el funcionament sa amb la malaltia per a buscar solucions. A més, necessitem conèixer bé la causa per a poder atacar-la. El problema és que moltes de les malalties neurodegeneratives tenen 
múltiples causes o causes desconegudes. Per exemple, el Parkinson i l'Alzheimer poden ser idiopàtiques (sense causa coneguda) o amb un origen genètic (una mutació familiar). $S$ 'han implicat mutacions en diversos gens en el desenvolupament d'ambdues, per exemple, en el cas de l'Alzheimer la proteïna beta-amiloide, diverses presenilines, la proteïna tau i l'apolipoproteïna E, mentre que parkina, alfa-sinucleïna i LRR2 s'han relacionat amb el desenvolupament del Parkinson.

En aquest punt, les malalties rares (malalties que afecten menys de cinc persones de cada 10.000 habitants) com ara el Huntington poden tenir una importància capital. Encara que la prevalença de la malaltia de Huntington és baixa en la majoria de les zones del planeta, ${ }^{4}$ és un model molt valuós per a la recerca bàsica. La malaltia de Huntington és una malaltia monogenètica, és a dir, la seua causa resideix en una mutació d'un únic gen. Aquest gen es troba en el cromosoma 4 i és el responsable de la producció d'una proteïna indispensable per a les cèl-lules, la huntingtina. Aquesta proteïna intervé en processos metabòlics i de control genètic, però la mutació que provoca la malaltia de Huntington la converteix en tòxica per a les neurones (Zuccato, Valenza i Cattaneo, 2010).

Malgrat la seua raresa en termes de freqüència, el Huntington comparteix les característiques del Parkinson i de l'Alzheimer, entre les quals trobem la manifestació durant l'edat adulta, la vulnerabilitat selectiva de certs tipus neuronals, ${ }^{5}$ i l'acumulació de proteïnes mutants a l'interior de les neurones: huntingtina al Huntington, beta-amiloide a l'Alzheimer, alfa-sinucleïna al Parkinson, etc. A més, aquestes proteïnes aberrants poden transmetre's de neurona a neurona de manera similar a com ho fan els prions (agents causants de la malauradament popular, fa uns anys, malaltia de les «vaques boges», Polymenidou i Cleveland, 2012). Per tant, entendre els mecanismes pels quals apareixen aquests problemes en el Huntington ens podria ajudar molt en el disseny de teràpies contra les altres malalties neurodegeneratives (Ross i altres, 2014).

\subsection{Tisores moleculars: noves eines de modificació del genoma}

Moltes malalties neurodegeneratives s'associen a mutacions en diversos gens. Per a poder reparar un gen defectuós es fa necessari l'ús d'eines que permeten manipular les molècules d'ADN. Les cèlllules posseeixen una mena de proteïnes capaces d'introduir talls en sequiències específiques d'ADN, una mena de tisores moleculars. Aquestes proteïnes es troben de manera natural en les cèlllules i permeten els processos d'autoreparació. Seria interessant poder dirigir aquests processos de reparació cap als gens que s'associen a les malalties neurodegeneratives.

\footnotetext{
${ }^{4}$ A Espanya van morir a prop de 900 persones diagnosticades amb la malaltia de Huntington entre 1981 i 2004. La malaltia de Huntington té una prevalença molt més alta en punts concrets del planeta, com per exemple les poblacions del voltant del llac Maracaibo a Veneçuela. Aquests punts han sigut valuosos per a la identificació de la mutació que causà aquesta malaltia el 1993.

${ }^{5}$ Les neurones més sensibles a la mutació de la malaltia de Huntington es troben en les estructures cerebrals denominades caudat i putamen, mentre que en el Parkinson la neurodegeneració es dóna preferentment a la substància negra. Ambdues regions pertanyen als ganglis basals, que es troben entre els circuits cerebrals que controlen el moviment. Per això, els símptomes més característics d'aquestes malalties impliquen una pèrdua del control motor.
} 
En les últimes dècades s'han identificat els mecanismes pels quals aquestes proteïnes poden reconèixer i unir-se a seqüències específiques de l'ADN, com per exemple el mecanisme dels dits de zinc (Isalan 2011). Aquestes proteïnes es poden combinar amb altres que tallaran l'ADN per a poder modificar els gens defectuosos, o amb altres que inhibiran la transcripció (vegeu la figura 2). Aquest fet ha implicat un espectacular avanç per a la teràpia gènica. Altres eines descobertes recentment en uns patògens de plantes, els TALEN, i en alguns bacteris, els CRISPR/Cas $9,{ }^{6}$ permeten una modificació molt ràpida i senzilla del genoma de les cèllules, la qual cosa promet interessantíssimes estratègies en un futur no massa llunyà (Shalem i altres, 2014).

Un exemple de la potència d'aquestes eines el proporciona el recent estudi clínic en pacients amb SIDA. Se sap que hi ha una mutació natural en algunes persones en un receptor de les cèl-lules T, que precisament és el que utilitza el VIH per a infectar-les. Les persones amb aquesta mutació són resistents a la infecció del virus, que no pot infectar les cèl-lules T del seu sistema immune. El que es va fer en aquest assaig va ser extraure sang dels pacients infectats, manipular les seues cèl-lules immunes per a introduir la mutació i tornar-les a trasplantar. Els resultats foren molt prometedors, amb una disminució significativa de la càrrega viral en els pacients que reberen aquest trasplantament (Tebas i altres, 2014).

\section{Teràpia gènica per a les malalties neurodegeneratives}

Fa mig segle, amb el naixement de la biologia molecular, Tatum (1966) va dir que podem ser optimistes sobre la possibilitat a llarg termini d'una teràpia que descobrisca, sintetitze i introduïsca nous gens en les cèlllules malaltes d'òrgans particulars. La idea era tan meravellosament simple que no podia fallar: si els metges foren capaços de trobar un gen malalt i reparar-lo, l'organisme es recuperaria. Tres dècades després, l'entusiasme era general: s'havia perfeccionat la tècnica d'administració de gens mitjançant l'ús de vectors vírics (Figura 2), i s'havien descobert eines de manipulació genètica com les proteïnes de dits de zinc.

Aquesta teràpia es beneficia de les capacitats dels virus d'infectar les nostres cèl-lules per a introduir els gens sans o factors genètics que siguen capaços de modificar els gens interns que causen la malaltia. L'esquema mostra, a l'esquerra, una cèlllula malalta per causa d'una mutació en un gen. La cèllula fa còpies del gen en forma d'ARN missatger (procés de transcripció, marcat amb una $a$ ), que al seu torn dóna la informació necessària per a produir una proteïna aberrant (procés de traducció, $b$ ). A la dreta, es mostra l'alliberament del gen terapèutic mitjançant vectors vírics. Una vegada dins de la cèl-lula, el gen terapèutic podrà reparar el gen o actuar sobre la seua transcripció i traducció, o podrà al seu torn utilitzar-se per a produir una proteïna terapèutica.

La teràpia gènica prometia curar pràcticament totes les malalties a curt termini, especialment aquelles causades per mutacions d'un únic gen. Aquell boom d'optimisme va patir un revés fatal amb les desastroses consequiències de diversos assajos clínics amb

\footnotetext{
${ }^{6}$ El descobriment de les aplicacions biotecnològiques del sistema CRISPR/Cas9, una mena de sistema immune bacterià, no és més que un dels nombrosos exemples sobre la necessitat d'invertir en ciència bàsica, ja que les aplicacions futures no són sempre visibles a curt termini.
} 


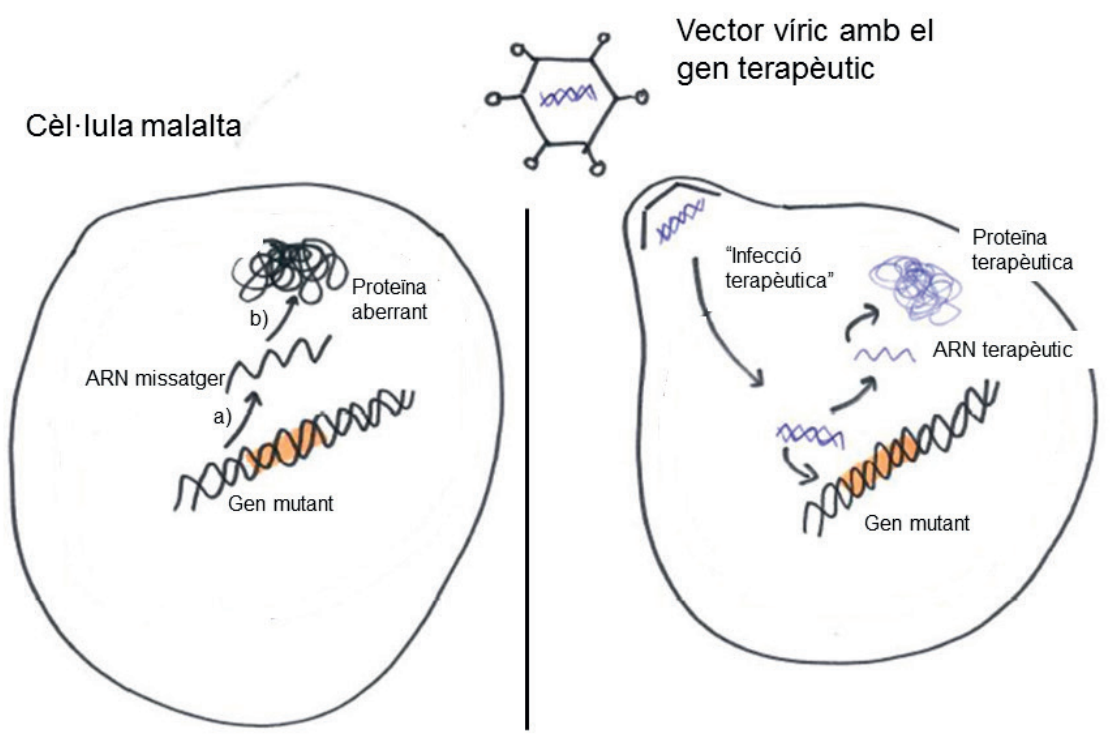

Figura 2. La teràpia gènica consisteix en la reparació, el reemplaçament o la modulació de l'activitat dels gens les mutacions dels quals causen una malaltia. ${ }^{7}$

pacients. Especialment dolorosa fou la mort d'un jove de 18 anys, Jesse Gesslinger, com a consequiència de la reacció immune contra el vector víric (Somia i Verma, 2000). Aquesta mort va posar en qüestió la teràpia gènica durant anys. Malgrat això, els científics han redoblat els seus esforços i han aconseguit vectors vírics segurs, amb reactivitat immune poca o nullla, que no es poden replicar ni escapar del cos de la persona tractada, que són meres càpsules per a introduir gens beneficiosos, ja que tot el genoma víric que podria ser patogen és eliminat mitjançant tècniques biotecnològiques. Aquests anys d'intensa investigació han donat els seus fruits i la teràpia gènica està florint de nou.

Com hem apuntat, les malalties idònies per a ser tractades amb aquesta aproximació són les malalties monogèniques com el Huntington, però inclús tractar-les aquestes no és senzill ja que, per exemple, se sap que la huntingtina interacciona amb més de 800 gens.

\subsection{Estudi experimental amb teràpia gènica en un model de ratolí de la malaltia de Huntington}

L'autora d'aquest article va participar en un estudi recent en un model animal amb una aproximació de teràpia gènica que emprava algunes de les eines descrites més amunt

\footnotetext{
${ }^{7}$ Hi ha un debat ètic sobre les conseqüències de la teràpia gènica. Els seus defensors argumenten que el seu objectiu és millorar la vida de les persones amb malalties greus, mentre que algunes persones i col-lectius de persones amb discapacitat la veuen com una espècie de nova eugenèsia.
} 
(Garriga-Canut i altres, 2012). En el laboratori del Dr. Mark Isalan, actualment a l'Imperial College de Londres, es van dissenyar unes proteïnes amb dits de zinc que reconeixien la mutació que causa la malaltia de Huntington. Aquestes proteïnes combinaven la zona de reconeixement amb una proteïna repressora de la transcripció (Figura 3A), de manera que podien evitar la producció d'ARN missatger de la huntingtina mutant. Després de comprovar l'eficàcia d'aquesta aproximació en cèl·lules de ratolí i de pacients en cultiu, vam administrar la proteïna terapèutica a un ratolí model de la malaltia de Huntington. Aquests animals són transgènics per a la seqüència mutant del gen de la huntingtina humana. Administrant la proteïna terapèutica directament al cervell dels ratolins (Figura 3B), vam poder comprovar que els ratolins tractats d'aquesta manera presentaven una freqüència menor de postures de «malaltia» que els seus controls no tractats (Figura 3C). A més, la quantitat d'ARN missatger i de proteïna mutant es trobaven disminuïdes en els ratolins tractats. Malgrat l'èxit inicial, traslladar aquests resultats a la clínica, si és que és possible, trigarà encara molts anys.
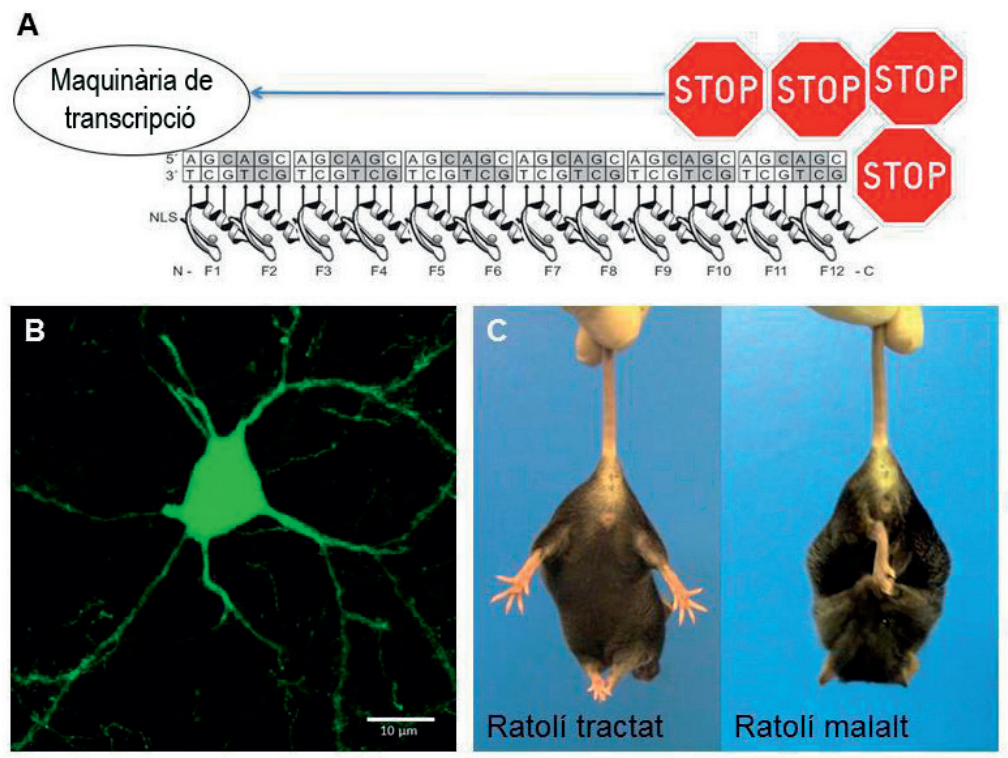

Figura 3. A. Esquema del mecanisme d'actuació de les proteïnes terapèutiques amb dits de zinc. B. Neurona del cervell d'un ratolí experimental que expressa un marcador que indica que la injecció del vector víric terapèutic ha estat efectiva (en aquest cas, proteïna verd fluorescent). C. A l'esquerra, ratolí tractat amb teràpia gènica, expressa el comportament normal d'escapament quan se l'agafa per la cua. A la dreta, un ratoli no tractat que expressa el comportament típic de la malaltia neurològica quan se l'agafa per la cua, és a dir, plega les potes i no mostra intenció d'escapar. L'esquema dels dits de zinc ha estat amablement cedit pel Dr. Mark Isalan.

Els dits de zinc reconeixen la mutació que causa la malaltia de Huntington, s'uneixen a l'ADN i impedeixen que es produesca l'ARN missatger, de manera que la proteïna mutant no es pot sintetitzar. 


\subsection{Teràpia gènica que funciona: èxit recent en el tractament de la leucodistròfia metacromàtica}

La leucodistrofia metacromàtica és una malaltia neurodegenerativa de tipus metabòlic causada per la deficiència en un únic gen. Aquest gen codifica un enzim, l'arilsulfatasa A, que s'encarrega de netejar l'acumulació de productes de rebuig a l'interior de les cèllules. La manca d'aquest enzim dóna lloc a l'acumulació d'aquests productes a les neurones, la qual cosa causa una neurodegeneració inexorable i provoca la mort dels malalts quan encara són nadons.

Els científics dissenyaren una estratègia terapèutica basada en l'autotrasplantament de cèlllules de la línia hematopoiètica, és a dir, cèlllules mare sanguínies dels mateixos pacients. S'extreuen aquestes cèlllules als nadons, es corregeix la mutació in vitro i es tornen a trasplantar les cèl-lules amb l'enzim funcional als pacients. Aquestes cèl-lules poden migrar cap al cervell i facilitar la neteja dels productes de rebuig. Els nadons que han rebut aquesta teràpia han sobreviscut, de moment, fins a dos anys, cosa impossible si no se'ls haguera tractat (Biffi i altres, 2013).

\subsection{Teràpia regenerativa per a les malalties neurodegeneratives}

La teràpia gènica és una eina de considerable utilitat per a malalties amb un origen genètic conegut, però per a malalties en les quals no hi ha un gen candidat són necessàries altres aproximacions. A més, com hem apuntant, sovint les neurones moren, la qual cosa fa necessari un trasplantament. En el cas que no hi haja un gen causant, se segueixen dues aproximacions que es poden combinar: la promoció de la síntesi de factors neurotròfics, és a dir, factors que promouen la supervivència i funcionalitat de les neurones, i els trasplantaments cellulars.

\subsubsection{Trasplantament de cèlllules encapsulades alliberadores de factors neurotròfics}

Com hem comentat, el cervell es troba ben aïllat i és molt difícil que els fàrmacs hi arriben si s'administren per rutes tradicionals. A més, els factors neurotròfics tenen una vida limitada dins del cos. És per això que la manera més efectiva d'aconseguir un alliberament continu de factors neurotròfics protectors la proporciona el trasplantament de cèlllules sanes que els produïsquen directament al cervell dels pacients. Però aquest trasplantament celllular té dos problemes fonamentals: el possible rebuig per part del sistema immune de les cèlllules que no siguen del mateix pacient i la possibilitat que les cèlllules proliferen de manera incontrolada.

Per a evitar ambdós problemes, és possible aïllar les cèlllules mitjançant la seua encapsulació en materials biocompatibles, que deixen passar lliurement els factors neurotròfics alliberats per les cèllules trasplantades. Aquesta estratègia s'ha utilitzat des de fa temps per a malalties com ara l'Alzheimer (Wahlberg i altres, 2012). Tot i que aquestes estratègies són prometedores, encara ens queden per superar problemes com són la distribució limitada dels factors o bé la impossibilitat de regenerar neurones perdudes quan la degeneració és avançada. 


\subsubsection{Trasplantament cel·lular per al Parkinson}

Els transplantaments de cèlllules fetals al cervell, capaces de proporcionar una funcionalitat similar a les neurones perdudes, s'han dut a terme des de fa bastant de temps per a malalties com el Parkinson. Recentment s'han reportat els beneficis que aquesta teràpia ha aportat a alguns pacients (Kefalopoulou i altres, 2014). No obstant això, l'ús de cèlllules embrionàries o fetals, a banda dels problemes ètics, pot presentar altres problemes com ara el rebuig per part del sistema immune del pacient.

Per a evitar aquest problema, en els últims anys s'ha avançat en la reprogramació de cèlllules adultes per tal de reconvertir-les a cèlllules mare o troncals, és a dir, cèlllules que tenen la capacitat de donar lloc a qualsevol teixit del cos humà. Aquesta tècnica, que va reportar el premi Nobel de Medicina a Shinya Yamanaka el 2012, permet extraure cèlllules adultes del mateix pacient, per exemple de la pell, i transformar-les en una placa en cèl-lules troncals que després es transformaran en neurones. Aquesta aproximació ja s'ha assajat amb èxit en animals experimentals amb Parkinson i és qüestió de temps que els assajos clínics donen fruits (Hargus i altres, 2010).

\subsection{Una nova fita de la biotecnologia: la biologia sintètica}

La disciplina de la biologia sintètica va nàixer com una branca de la biotecnologia fa pocs anys, i el seu objectiu principal és l'estandardització de components biològics reutilitzables per a construir nous dispositius biològics. Aquest objectiu s'acompleix mitjançant la combinació i la reconnexió de diferents mòduls genètics.

Una de les ambicions dels biòlegs sintètics és la creació de cèllules sintètiques que estiguen equipades amb xarxes genètiques, com una mena de programes de computació per a poder trasplantar-les als pacients, i que duguen a terme l'alliberament controlat de fàrmacs o altres biomolècules terapèutiques. El control de l'alliberament es porta a terme equipant les cèlllules artificials amb sensors o receptors que siguen capaços d'activar la producció dels fàrmacs com a resposta a un senyal extern. Normalment, el senyal extern pot ser a la seua vegada un fàrmac (per exemple, un fàrmac que ja es prenga el pacient per a tractar la seua malaltia, de manera que es combinen les dues teràpies), o un canvi que tinga lloc en el cos del pacient (per exemple, un increment dels nivells d'alguna hormona que, en si mateix, puga ser patològic).

Seguint aquesta estratègia, s'han construït diverses cèl-lules artificials amb receptors per a neurotransmissors i hormones, que són capaces d'alliberar fàrmacs quan hi ha un canvi en la concentració d'aquests. Per exemple, una de les cèllules artificials portava un receptor del neurotransmissor dopamina que, en activar-se, alliberava una molècula antihipertensiva natural, el pèptid natriurètic atrial (PNA). Els investigadors van trasplantar aquestes cèllules a ratolins hipertensos. Van comprovar que la producció de PNA s'incrementava en tractar els ratolins amb un fàrmac agonista de la dopamina (és a dir, un fàrmac que estimula el receptor de dopamina amb el qual les cèllules terapèutiques anaven equipades). Però a més, van comprovar que nivells elevats de dopamina de manera natural, en un encontre sexual amb femelles dels ratolins implantats, aconseguien també alliberar PNA, de manera que la hipertensió produïda per l'encontre sexual quedava atenuada (Rössger, Charpin-El Hamri i Fussenegger, 2013). 
Encara que aquesta tecnologia sembla ciència ficció i es troba en un estat encara embrionari, podem preveure un futur en el qual es construesquen cèl-lules receptores per a biomarcadors de malalties neurodegeneratives que siguen capaces de detectar canvis predictors de la malaltia. Per exemple, recentment s'ha publicat que la disminució de deu biomolècules lipídiques (greixos) en la sang de pacients d'edat avançada prediu l'aparició de demència o Alzheimer en els següents dos-tres anys (Mapstone i altres, 2014). Construir cèl-lules artificials capaces de sentir variacions en aquests lípids i començar a alliberar factors neuroprotectors abans de l'aparició dels símptomes podria ser una estratègia viable. Per descomptat, els trasplantaments d'aquest tipus de cèl-lules s'haurien de restringir a la població susceptible de patir la malaltia.

\section{Conclusions i una mirada al futur}

El segle Xxi és, sens dubte, el segle del cervell. La investigació sobre l'òrgan més complex del nostre cos ha experimentat avenços increïbles en pocs anys, i els esforços econòmics dels governs per al finançament d'estudis sobre el sistema nerviós són notables. No obstant això, sembla que només hem pogut albirar uns pocs aspectes del funcionament del nostre cervell.

Les noves eines biotecnològiques prometen noves fites per al tractament de les malalties neurodegeneratives en un futur no molt llunyà (Agustín-Pavón i Isalan, 2014). Amb tot, és possible que l'estratègia de tractament que més èxit comporte siga la d'ajudar el nostre cos a autoreparar-se mitjançant la promoció dels mecanismes intrínsecs de reparació que posseïm. Fa algunes dècades, tots els llibres deien que al cervell adult no existia la generació de noves neurones. Avui sabem que això no és cert. Se sap que la generació de noves neurones continua durant tota la vida de l'individu, encara que només en uns pocs llocs del cervell. Recentment s'ha descobert que noves neurones són incorporades al nucli caudat i al putamen dels humans durant tota la vida, les regions cerebrals que abans es degeneren en la malaltia de Huntington. A més, s'ha comprovat que aquest procés es troba afectat en els pacients d'aquesta malaltia (Ernst i altres, 2014). Per tant, una comprensió profunda d'aquest fenomen ens permetria utilitzar les eines biotecnològiques per a dissenyar cèllules intel-ligents que alliberaren factors de promoció de la neurogènesi adulta i ajudaren aquestes cèllules generades pel mateix cervell a reparar-lo.

La millora en les eines diagnòstiques, que permetrà un inici primerenc dels tractaments, junt amb aquestes noves estratègies terapèutiques biotecnològiques, assegurarà que puguem combatre de manera més eficaç unes malalties cada vegada més presents en la nostra societat envellida.

\section{BIBLIOGRAFIA}

Agustín-Pavón C. i M. IsAlan (2014): «Synthetic biology and therapeutic strategies for the degenerating brain», Bioessays, 36, 979-990.

Alzheimer Association (2014): «2014 Alzheimer's Disease Facts and Figures», Alzheimer's \& Dementia, 10(2), e47-92, <http://linkinghub.elsevier.com/retrieve/pii/S1552526014000624>.

BIfFI, A. i altres (2013): «Lentiviral Hematopoietic Stem Cell Gene Therapy Benefits Metachromatic Leukodystrophy», Science, 341, 6148, <http://www.ncbi.nlm.nih.gov/pubmed/23845948>. 
Doty, R.L. i K. Vidyulata (2014): «The Influences of Age on Olfaction: A Review», Frontiers in Psychology, 5, 20.

ERnst, A. i altres (2014): «Neurogenesis in the Striatum of the Adult Human Brain», Cell, 156(5), 1072-1083.

FonG, H. i altres (2013): «Genetic Correction of Tauopathy Phenotypes in Neurons Derived from Human Induced Pluripotent Stem Cells», Stem Cell Reports, 1(3), 226-234.

Garriga-Canut, M. i altres (2012): «PNAS Plus: Synthetic Zinc Finger Repressors Reduce Mutant Huntingtin Expression in the Brain of R6/2 Mice», Proceedings of the National Academy of Sciences, 109(45), 3136-3145.

Hargus, G. i altres (2010): «Differentiated Parkinson Patient-Derived Induced Pluripotent Stem Cells Grow in the Adult Rodent Brain and Reduce Motor Asymmetry in Parkinsonian Rats», Proceedings of the National Academy of Sciences of the United States of America, 107(36), 15921-15926.

Isalan, M. (2011): «Zinc-Finger Nucleases: How to Play Two Good Hands», Nature Methods, 9(1), 32-34.

Kefalopoulou, Z. i altres (2014): «Long-Term Clinical Outcome of Fetal Cell Transplantation for Parkinson Disease: Two Case Reports», JAMA Neurology, 71(1), 83-87, <http://www.ncbi.nlm.nih. gov/pubmed/24217017>.

Mapstone, M. i altres (2014): «Plasma Phospholipids Identify Antecedent Memory Impairment in Older Adults», Nature medicine, 20(4), 415-418, <http://www.ncbi.nlm.nih.gov/pubmed/24608097>.

Morley, J.F. i altres (2011): «Olfactory Dysfunction Is Associated with Neuropsychiatric Manifestations in Parkinson's Disease», Movement Disorders, 26, 2051-2057.

Polymenidou, M. i D.W. Cleveland (2012): «Prion-like Spread of Protein Aggregates in Neurodegeneration», Journal of Experimental Medicine, 209, 889-893.

Ross, C. i altres (2014): «Huntington Disease: Natural History, Biomarkers and Prospects for Therapeutics», Nature reviews. Neurology, 10(4), 204-216, <http://www.ncbi.nlm.nih.gov/pubmed/24614516>.

Rössger, K. i altres (2013): «Reward-Based Hypertension Control by a Synthetic Brain-Dopamine Interface», Proceedings of the National Academy of Sciences of the United States of America, 110(45), 18150-18155, <http://www.scopus.com/inward/record.url?eid=2-s2.0-84887315800\&part nerID=tZOtx3y1>.

Shalem, O. (2014): «Genome-Scale CRISPR-Cas9 Knockout Screening in Human Cells», Science, 343, 84-87, <http://www.ncbi.nlm.nih.gov/pubmed/24336571>.

Somia, N. i I.M. Verma (2000): «Gene Therapy: Trials and Tribulations», Nature reviews. Genetics, $1(2), 91-99$.

Tatum, E.L. (1966): «Molecular Biology, Nucleic Acids, and the Future of Medicine», Perspectives in Molecular Medicine, 10(1), 19-32.

Tebas, P. i altres (2014): «Gene Editing of CCR5 in Autologous CD4 T Cells of Persons Infected with HIV», The New England journal of medicine, 370, 901-910, <http://www.ncbi.nlm.nih.gov/ pubmed/24597865>.

WAHLberg, L.U. i altres (2012): «Targeted Delivery of Nerve Growth Factor via Encapsulated Cell Biodelivery in Alzheimer Disease: A Technology Platform for Restorative Neurosurgery», Journal of Neurosurgery, 117(2), 340-347.

Zuccato, C. i altres (2010): «Molecular Mechanisms and Potential Therapeutical Targets in Huntington's Disease», Physiological reviews, 90, 905-981.

\section{BIONOTA}

\section{Carmen Agustín Pavón}

PhD. Professora Ajudant Doctora de la Unitat Predepartamental de Medicina de l'UJI. Després de fer el Doctorat en Neurociències de la Universitat de València amb Premi Extraordinari en l'àrea de Salut, ha estat investigadora en centres del màxim prestigi internacional, incloent-hi la Universitat de Cambridge (Regne Unit), el Centre for Genomic Regulation (CRG, Barcelona) i l'Imperial College de Londres (Regne Unit). 